\title{
Geoportal as a means to popularize geological heritage of Ukraine
}

\author{
Vitalii Zatserkovnyi ${ }^{1}$, Nataliia Oberemok ${ }^{2}$, Polina Berezina ${ }^{3}$ \\ Taras Shevchenko National University of Kyiv \\ 90, Vasylkivska str., Kyiv, Ukraine, 03022 \\ ${ }^{1}$ vitalii.zatserkovnyi@gmail.com, orcid.org/0000-0003-2346-9496 \\ 2oberemokn@gmail.com, orcid.org/0000-0002-7230-8149 \\ 3 polin.berezina@gmail.com, orcid.org/0000-0002-9877-0585
}

The manuscript was received on 27.03.2017 and was accepted after revision for publication on 18.10.2017

DOI: $10.26884 / 1707.1201$

\begin{abstract}
The article discusses issues of using geological natural monuments (GNM) for scientific and educational purposes. It is a part of a general problem of preservation and use of geological heritage of the Earth, which has become internationally important lately. Local and international practice shows the need for thematic geotours that heavily rely on geological natural monuments.

Geological tourism has a potential to improve socio-economic situation of local communities in Ukraine, to preserve and popularize Earth sciences. As of this day, there are no means to draw public attention to Ukrainian geoheritage and geotourism, which makes this research highly relevant.

Geoportals and web GIS components will enable ordinary citizens to interact with a map of Ukrainian GNM, obtain interesting information, thereby getting involved in geological tourism themselves. To achieve this goal, the following goals were accomplished: gathering information on geoheritage in Ukrainian regions, designing and filling a database, creating interactive maps, developing a concept and a prototype of a corresponding geoportal.

The article starts by explaining the concepts of geological tourism, natural monuments and their significance. Discussed are important related concepts as geoheritage, geoheritage and geopark. Further described is the classification of geological landmarks. The main part introduces a concept of geoportals and methodology to develop a geoportal about geological tourism in Ukraine. It is expected that a developed geoportal with web GIS will encourage sharing within general audience and systematize information about objects of geological heritage in Ukraine.
\end{abstract}

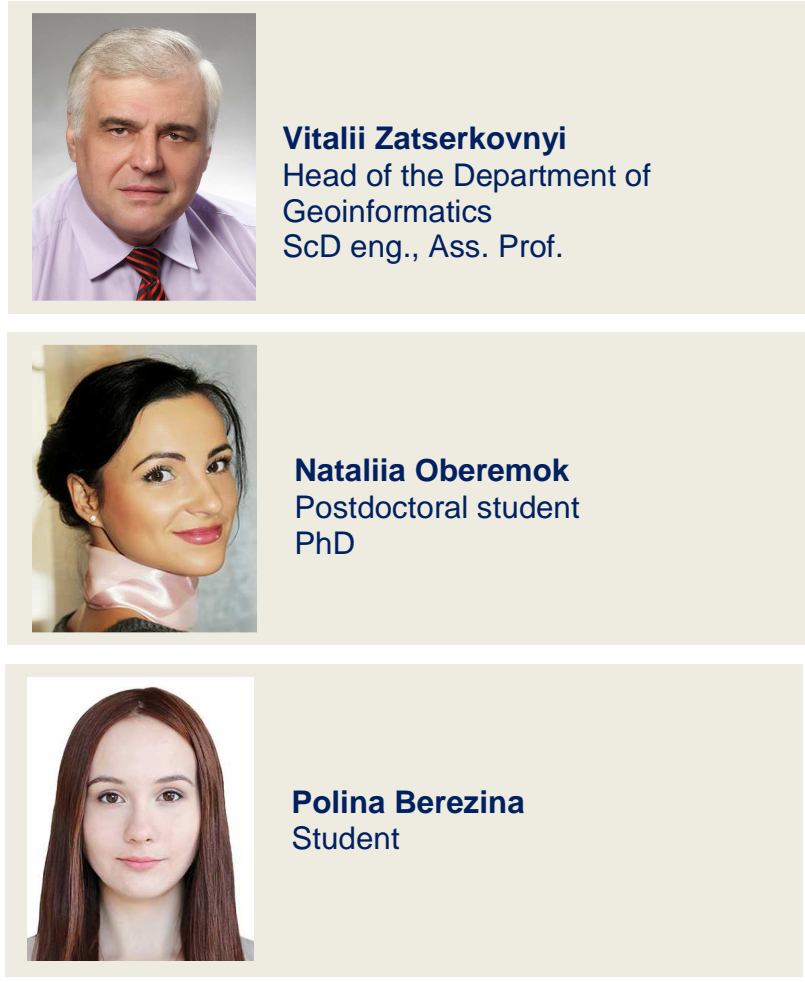

Keywords: geotourism, geological tourism, geological natural monuments, geoportal, web GIS, spatial database.

\section{INTRODUCTION}

Research problem. Geological tourism is an important part of tourism, because it provides essential insights into the past of a region and prospects for its future development. Despite the economical crisis in Ukraine, tourism industry has been remaining stable. Conditions 
that allow it include advantageous geographical location, significant recreational potential, favorable climatic conditions, well-developed transportation network, abundant natural and cultural heritage. Ukraine is a unique country in Europe due to its various natural resources, unique landforms, relict flora and fauna, diverse and unique culture. However, there are issues that prevent development of a novel type of tourism, namely, geological tourism.

Aspects of the problem. Among unresolved problems of geological tourism highlighted is the problem of insufficient information coverage of geological heritage, lack of transportation infrastructure and facilities, inappropriate conditions of the natural landmarks etc. In addition, there are a number of obsolete laws and regulations about protected areas that hinder the development of natural parks, hence, any form of tourism in the areas. It becomes a major obstacle to popularize certain routes.

Relevance of the research lies in novelty of geological tourism to engage people in recreational and scientific activity while preserving geosites. Development of geotourism in Ukraine, a country that has multiple prominent geological landmarks, creates an opportunity to promote this niche to an international level, improve socio-economical situation, preserve nature and popularize geosciences.

Recent research and publications. Ukrainian Society for Nature Conservation and the Ministry of Geology of the USSR publicized first academic works on the importance of environmental protection and conservation of geological heritage in the 1960 s. In 1984, there was a geological map of attractions Ukraine published (O.I.Zaryckyj, N.E.Korotenko, K.O. Sukhodolskyi, O.S.Shyrytsya); in 1985 a publisher "Naukova dumka" printed a reference book and a guide "Geologicheskiye pamyatniki Ukrainy" (Geological landmarks of Urkaine) (auth. N.E.Korotenko, O.S.Shyrytsya, A.Y.Kanyevskyy et al.). This followed published guides to several regions of Ukraine (V.G.Ena "Landshaftnyye pamyatniki" (Landscape monuments), 1966; V.I.Lebedynskyy "Geologicheskiye ekskursii po Krymu" (Geological tours of Crimea), 1976 etc. Thus, the 1960 - 1980 s was the beginning of a long- term focus on identification, certification and the assignment of status of protected areas to Ukrainian geological landmarks.

Subsequently, a fundamental work "Heolohichni pamyatky Ukrayiny" (Geological landmarks of Ukraine) [2] was published, the European Association for the protection of geological heritage and the European register of geological objects of Ukraine were established; International Union of Geological Sciences created a project Geosites under the auspices of UNESCO etc.

Academics N.P.Gerasimenko, A.A.Ishchenko, V.V.Manyuk, V.P.Gritsenko study issues of identification and protection of geological sites. M.V.Kosmachova's works are dedicated to ranking geological and geographical natural landmarks according to of their scientific, educational and practical importance [9]. Since 2006 there were two international conferences in Ukraine on environmental protection in the geological field and popularization of geolandmarks [12].

Application of geographic information systems (GIS) for the geological tourism was developed first for Crimean region [13]. In 2011, National Service of Geology and Mineral Resources of Ukraine announced a project " $\mathrm{Ca}$ pacity development of geographic information industry in Ukraine" under a bilateral FinnishUkrainian program. It included development of a web portal with a section devoted to "Geological Tourism" [14]. Unfortunately, the web portal does not function. All of this resultes in a shortage of information resources to draw public attention to geological landmarks, popularize geoheritage and importance of geoconservation.

A term "geotourism" was first introduced by a British scientist Thomas Hose: "The provision of interpretive and service facilities to enable tourists to acquire knowledge and understanding of the geology and geomorphology of a site (including its contribution to the development of the Earth sciences) beyond the level of mere aesthetic appreciation" [3]. Based on conducted studies, a Polish researcher Piotr Mihon [1] indicated that a prefix "geo" relates to "geology, geomorphology and natural features of the landscape such as land- 
forms, fossils, rocks and minerals, with a focus on identifying and understanding processes that formed these elements of the environment".

Polish authors Tadeusz Slomka and Alicja Kisieska-Svidzerska [1] emphasize educational and emotional aspects associated with visiting geological and geomorphological sites. According to them, geotourism is a type of tourism based on studies of geological (geomorphological) objects and processes, as well as on aesthetic impressions about the natural site.

\section{METHODOLOGY}

The aim of the work is popularization (and, eventually, commercialization) of geological heritage on the Internet using a web technologies and server GIS, which are cornerstones of a geoportal (geographical web portal). Geotourism can be defined through a didactic function, and its main goal is to interpret scientific knowledge in geology and geomorphology for public.

The objectives are to design and fill a spatial database of Ukrainian geological landmarks, develop of a fully-functional prototype of a geoportal about geotourism with web maps, multimedia and informative content.

The research object are geological landmarks of Ukraine, attracting them to the hiking trails will promote their preservation and promotion.

\section{RESULTS}

To analyze the prospects of tourism industry in Ukraine, one must emphasize that tourism sphere intertwines both economical and social factors. Precisely society should be central to novel national tourism policies, development of which can positively influenceeconomic and social situation of Ukraine, stimulate a number of important sectors,improve an image of Ukraine in the global arena. There was a SWOT analysis conducted (Table 1) to confirm the for geotourism development.
The following are the most important characteristics of geological tourism [8]:

- protects and preservs the environment;

- stimulates infrastructure development and socio-economic growth of local communities;

- involves educational activities within the geosciences.

Lack of available and integrated tourism database rather reduces possibilities of promoting this new and attractive type of activity. Therfore, systematic work aimed at registration, accounting and visualization of information on geosites is highly important.

Since 2004 UNESCO strongly supports geotourism for educational, environmental and socio-economical factors. The Division of Ecological and Earth Sciences at UNESCO presented a new concept called "International Geosciences and Geoparks Programme", and in 2002 there was a special UNESCO program launched called "Global Network of National Geoparks". Currently, it includes 120 geoparks in 33 countries [9].

This concept is consistent with the trend of integration of science and culture, while recognizing the importance of preserving the physical landscape. In addition to educational and training opportunities, tourism facilities have a great potential to increase awareness and understanding of geological heritage and environmental protection. During geotourism activities, the audience, children or adults, locals or tourists, can learn about the geological history of the area directly and comprehend various geological processes. This is a clear communication of science to the general public.

A geological landmark is a unique natural or anthropogenic object that characterizes local and/or regional geological processes and their results; has a scientific, historic, aesthetic, and educational value [15]. To map these sites on web, we used the following classification of geological natural landmarks [10]: mineralogical - sights with mineral resources; petrographic - rock outcrops that are characteristic of certain petrographic formations; stratigraphic - outcrops of stratified formations that characterize relative geological age of these rocks; hydrogeological - unique 
Table 1. SWOT analysis of geotourism development in Ukraine

\begin{tabular}{|c|c|}
\hline Strengths & Weaknesses \\
\hline $\begin{array}{l}\text { - convenient economic and geographical position; } \\
\text { - significant natural and recreational potential of } \\
\text { protected areas (about } 4 \% \text { of the national territory), } \\
\text { which can be a possible site of geoparks } \\
\text { • contributes to other alternative types of tourism } \\
\text { (educational, sports, green, agro- tourism etc.) } \\
\text { • abundant natural and recreational resources } \\
\text { - increasing rates of infrastructure development for } \\
\text { recreational use } \\
\text { • wealthy historical and cultural heritage, unique } \\
\text { ethnic and cultural identity of Ukrainians; plentiful na- } \\
\text { tional traditions and crafts, festivals } \\
\text { • multiple historical and cultural monuments (about } \\
\text { 130,000 monuments) }\end{array}$ & $\begin{array}{l}\text { - negative image of the country due to political } \\
\text { issues and conflict in the Eastern Ukraine } \\
\text { • slow economic development } \\
\text { - insufficient information provision } \\
\text { • underdeveloped social, industrial, service in- } \\
\text { frastructure } \\
\text { • poor training of locals in the service and tour- } \\
\text { istm area } \\
\text { • underestimation of the value of natural land- } \\
\text { marks by locals } \\
\text { - unsatisfactory condition and quality of trans- } \\
\text { port services } \\
\text { • poor maintenance of historical and cultural } \\
\text { monuments } \\
\text { • weak support from the government and pri- } \\
\text { vate sector } \\
\text { - underfunded scientific research in earth sci- } \\
\text { ences }\end{array}$ \\
\hline & nities \\
\hline $\begin{array}{l}\text { • poor coordination between organizations involved } \\
\text { in geotourism and green tourism } \\
\text { • lack of common strategic objectives for geotour- } \\
\text { ism development } \\
\text { • unstable political and economic situation is not } \\
\text { conducive to foreign investors } \\
\text { • damage and destruction of geological objects dur- } \\
\text { ing tourism activities } \\
\text { • overuse and depletion of natural resources } \\
\text { - negative impacts of natural disasters on the objects } \\
\text { of geotourism } \\
\text { - insufficient control over the use of natural re- } \\
\text { sources (deforestation, unauthorized hunting, fishing } \\
\text { etc.) } \\
\text { - insufficient educational provision for geotourism } \\
\text { activities }\end{array}$ & $\begin{array}{l}\text { - socio-economic growth, since geotourism de- } \\
\text { velopment promotes capital inflow, creates em- } \\
\text { ployment opportunities and improves the quality } \\
\text { of life } \\
\text { • influx of tourists contributes to protection and } \\
\text { restoration of cultural and historical monuments } \\
\text { • geoparks (especially with a member status of } \\
\text { the European Geoparks Network) can ensure pres- } \\
\text { ervation of geological heritage } \\
\text { - new tourism infrastructure and trails } \\
\text { - improvement of rural dwellings, rural social } \\
\text { infrastructure, services etc. } \\
\text { - increased international cooperation and ex- } \\
\text { change of experience in geotourism, green tourism }\end{array}$ \\
\hline
\end{tabular}

groundwater springs; paleontological - sights with fossils of ancient organism; geochronological-reflecting the chronological sequence of rock formations; tectonic - sites with evidence of crustal movements, geological structures; complex - several classes of geological landmarks. This classification was expanded to provide users with a more detailed information to 15 classes. which belong to the classification system developed in the work [4]. Additional classes include volcanic, geomorphological, speleological, cosmogenic, historical mining, glacial, coastal and aquatic, museum collection. Although this classification provides types according to subject and genetic principles, this expansion has a great advantage (namely, an opportunity to choose from a greater number of classes) in the context of interaction with future geoportal users.

For the last years, the use of GIS for tourism management and planning has been increasing [15]. Existing geographic information systems, literature, reports from government institutions, and public data provide a large volume of material for identification of potential geotourism areas. Analysis of their tourism potential in the context of other environmental and infrastructure datasets can be done with 
GIS tools. It is also possible to analyze suitability of these areas with several geoprocessing tools, such as buffer analysis of potential threat areas or analysis of access level for different visitors (analyzing types and slopes of surfaces), distance to existing tourism clusters, etc. [16].

Despite apparent disadvantages, scanned paper maps are still widely used. However, over time these static maps will be replaces with interactive computer versions [15]. For example, a user of a tourism geoportal has a possibility plan a route, click on symbols on the map to obtain detail content make requests, view photos, and navigate to related sites, and receive information about accommodation and tours.

Technological advancement provided new tools, user interface and options to interact with web maps. For instance, these platforms include Google Maps, ArcGIS Online, MapBox, GISCloud, MangoMap, NextGIS, CartoDB and others. They provide to a publisher web applications, mapping services, which can be embedded with HTML code into other web pages.

Web technologies are an extremely powerful tool and relatively inexpensive compared to traditional printing. Geotourism as a new and attractive industry can use these benefits to popularize geological heritage and market touristic activities on geosites. The conceptual idea is to visualize a desired image of a specific destination for future visitors, while providing comprehensive information, interesting and interactive science communication content. Web GIS is the best option to achieve

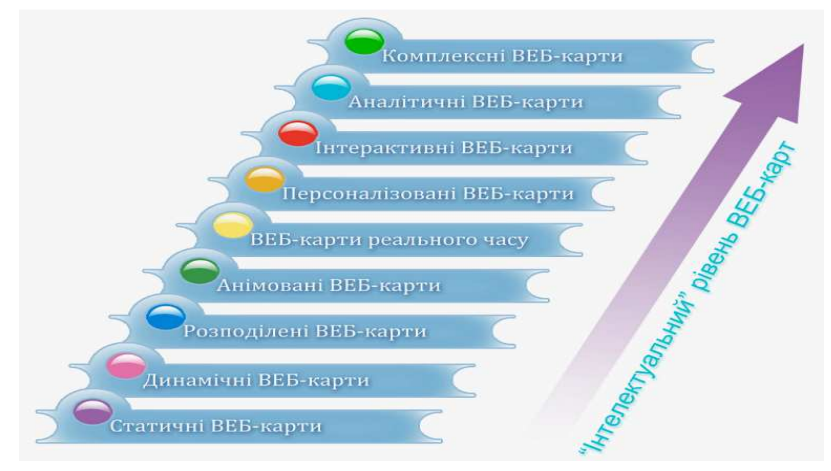

Fig.1. Increasing the "intellectual" level of web maps those goals by transmission of spatial and attributive information. Web technologies can significantly improve "intelligence" of generated thematic maps (Fig.1) [15].

Phases of the web portal development for geotourism industry are introduced on Fig.2.

The following features will be implemented on the geoportal about geotourism in Ukraine in the order of importance:

- publication and search for GIS resources;

- publication of information on geological landmarks and multimedia content;

- simple queries (identification of objects, filtering of attributes etc.);

- support for multiple languages;

- individualization geoportals, namely, support for user profiles.

It was decided to use the existing web platforms - ArcGIS Online and Web Applications. Ready-made technological solutions can significantly shorten a web development time and allow to focus on concepts, purpose and design of future web products. In addition, this platform is free for a limited use and universal. The problem of this solution is that web applications do not integrate a service and database connection with a free license. As a solution, open-source tools can be used such as Boundless Suite that packages several programs and libraries for coherent data management and building web maps. Open-source software is low-cost, free to use and modify compared to proprietary software. However, it is not straightforward to use, which means longer product development and need for technological support; open-source software also often has issues with compatibility.

A database management system (DBMS) was used to manage spatial information on geological landmarks. The relational database was designed to effectively store, create relations between stored items and query them. Queried results are output as a table and provide necessary information on geosites. These are further shown in a GIS software, on a web map or geoportal. Such queries allow fast processing of spatial data, such as changing the geometry and projection, filtering and modifing items etc. 


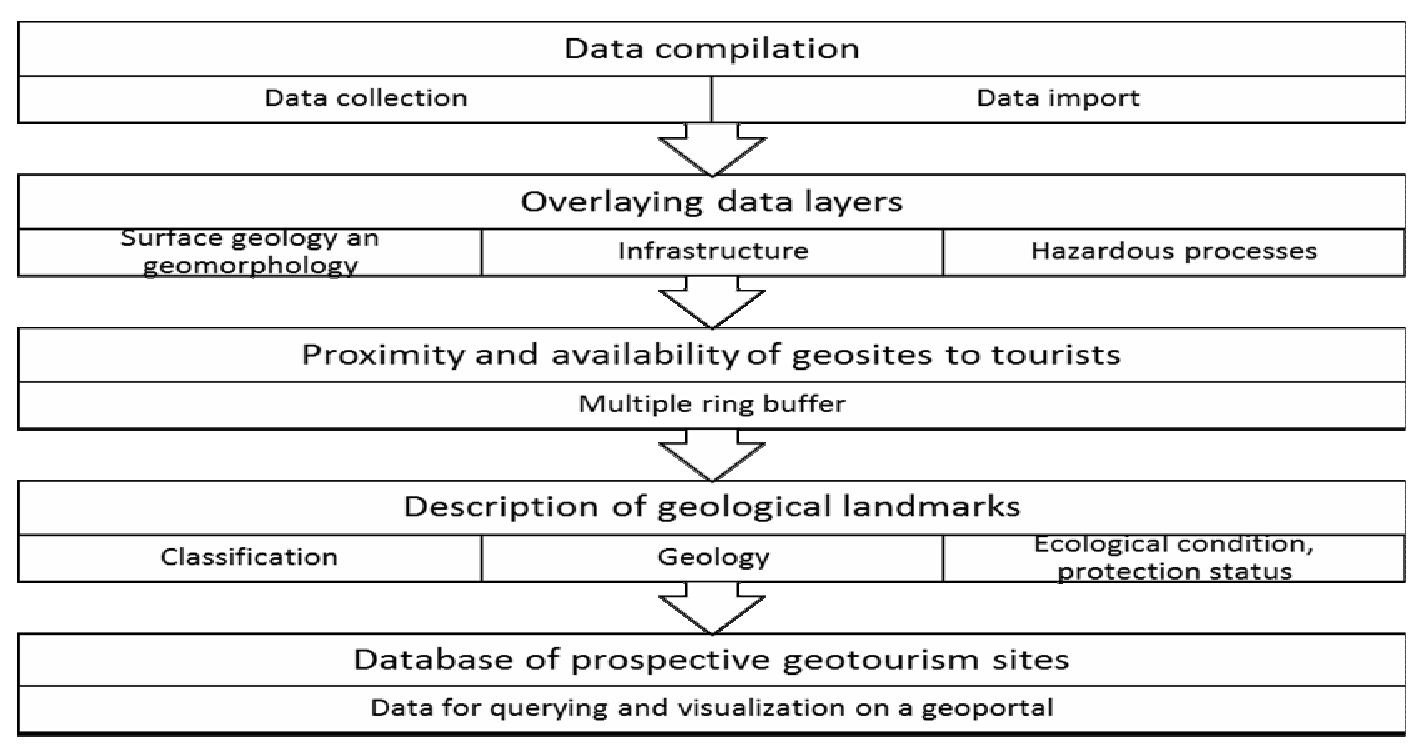

Fig.2. Phases of the geotourism web portal development

PostgreSQL is a popular open-source object-relational DBMS. With the PostGIS spatial extension, it allows organizing, visualizing and analyzing spatial data. As a result, this DBMS made it possible to efficiently store and process coordinates and attributive information of selected geological landmarks. This can also be achieved in a GIS software (ArcGIS, QGIS etc.). However, an object-relational DBMS was chosen for several advantages:

1) it creates more complex spatial relations and queries;

2) allows integrating data to any other database or exporting to multiple file formats;

3) easily introduces relationships between fields and hierarchical database models;

4) natively uses SQL language.

The first step was designing such a PostgreSQL database (Fig.3). Such relationships and tables were created so as to provide a user with a brief but informative description of a geolandmark, such as name, location, coordinates, text description, classification, tectonic structure, official registration status of a protected area, web links to multimedia content (photographs).

The classification table consists of 15 items according to the previously given classification of geological natural landmarks. A user is able to obtain chrono-stratigraphic relationships due to the hierarchical relations between tables (relations "father" - "child"). For exam- ple, after making a query for Precambrian geological objects, the user will be given objects that span all eras and periods of Precambrian. This is accomplished by using the server-side programming language (e.g. PHP, Python).

There were nearly 400 geological natural landmarks added to the database; the majority of them are prospective geotourism sites. Spatial and attribute information was collected from the books "Geologichni pamiatky Ukrayiny" (Geological landmarks of Ukraine) [2], open Wikipedia data and governmental reports on natural reserve fund. We should recognize that there are potential limitations associated with existing data on the geological monuments and tourism in Ukraine. For lessdocumented areas, more information can be acquired through field studies and on-site documentation.

Subsequently, point features are visualized using ArcGIS Online and ArcGIS Web Application. The free license allows uploading geospatial data files, viewing and editing them as a table, customizing web visualization. ArcGIS Web Application is simple analogue of geoportals used by scientists, journalists and organizations around the world to publish maps and data visualizations, to present multimedia and text content. Web Application is generally used for storytelling or integration with enterprise solutions and server support for governmental and research projects. 


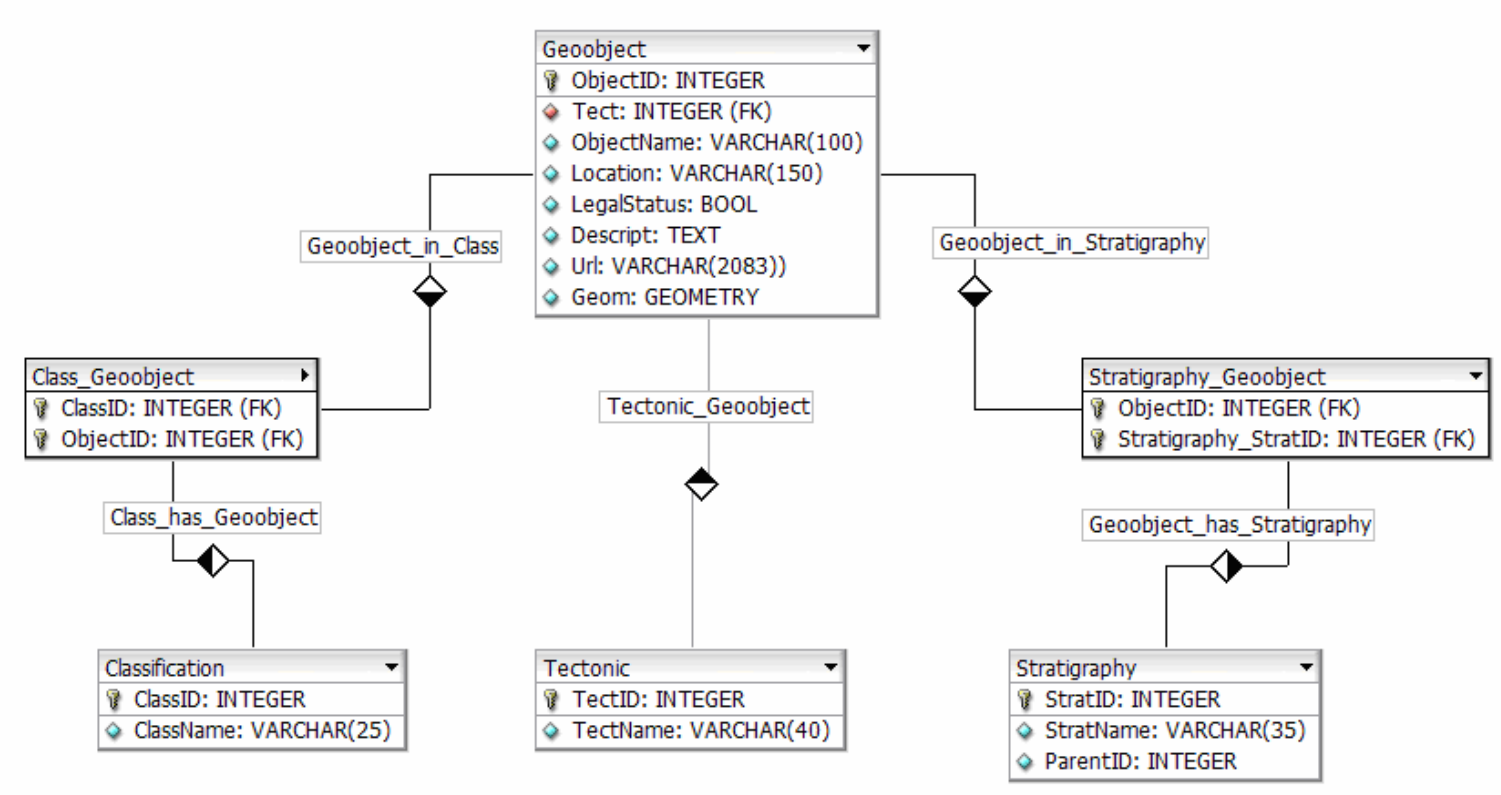

Fig.3. Design of the geotourism database in PostgreSQL DBMS

In the absence of configured web server, the local PostgreSQL database was exported in .csv file extension with joined rows from related tables. Geographic coordinates were presented in a popular web mapping projection WGS84 3857. With enterprise server technologies, such as ArcGIS Server, the web maps or GIS on the web-portal could be directly connected to the database, query it with a server-side programming language, and update the map for the user with results.

The prototype of geoportal on ArcGIS Online includes the following thematics maps, after the introduction to the concept and importance of geological tourism (Fig.4) [2, 17 20]:

- geoparks of Europe within the framework of the UNESCO Global Geoparks (Fig.5);

- map of geoheritage. It provides users with important all available information from the database about geological landmarks with a photo (Fig.6);

- map of classification of geological landmarks. There users are able to browse classified landmarks according to a symbology (Fig.7). In the future, it is planned to integrate this map and the previous larger dataset;

- map that represent number of geological landmarks (officially protected areas and not) listed in the database per an administrative- territorial unit (Fig.8). It allows identifying potential areas for geotourism development due to larger clusters of geoheritage.

A code popup window on the ArcGIS Online web map can be edited, which allows changing display order of fields, customizing text and adding pictures. When a user clicks on a location point on the map, a new window popup shows visual and textual information from exported .csv file. For example, Fig.9 represents popup window at a local geological landmark "Kanevsky Cuesta".

Furthermore, the database, web maps and web GIS can be publicized offline, for example, on CD/DVD, to popularize geotourism and geosciences. Maps can be imbedded into web sites of Ukrainian organizations and governmental agencies, or burnt to compact disks with additional multimedia content in order for educational activities in schools. This educational application of the geoportal may considerably enhance the interest of young people to geological heritage, encourage further studies and protection of geological sites in their region.

\section{CONCLUSION}

Geotourism is an activity of exploring nature and geological sites, studying geo- 


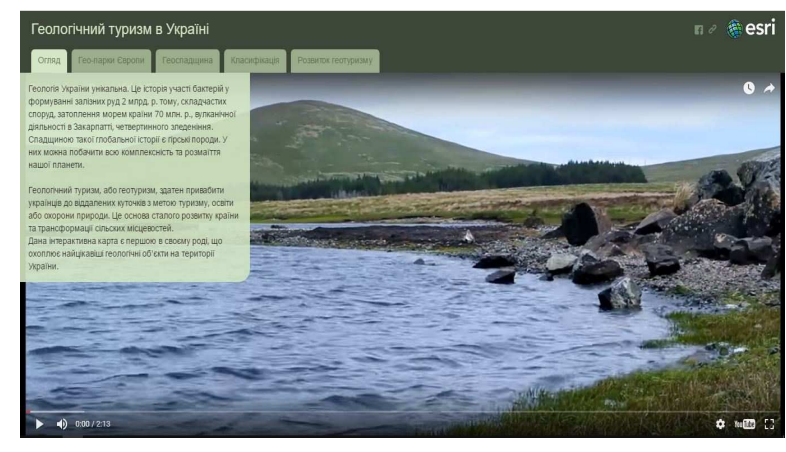

Fig.4. Introduction to geological tourism

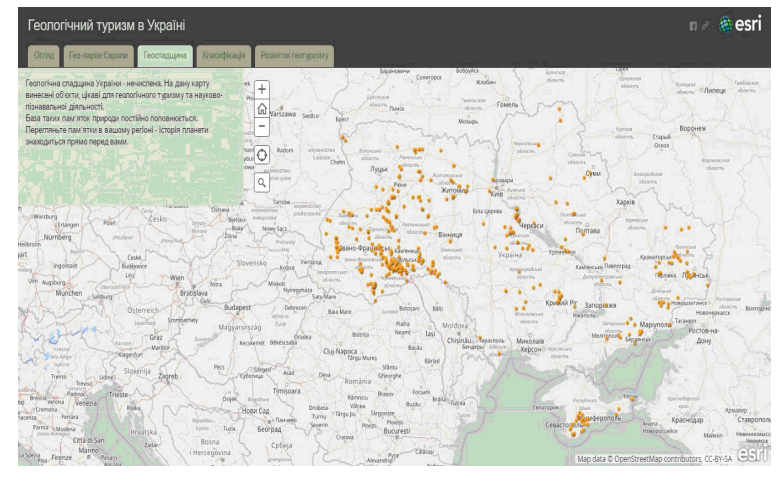

Fig.6. Geoheritage of Ukraine

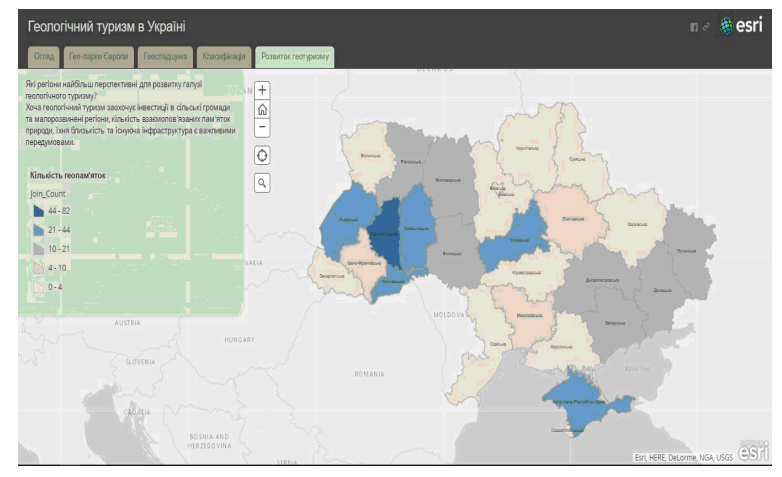

Fig.8. Number of geological landmarks per an administrative-territorial unit

sciences, and participating in environmental protection. On the other hand, geological tourism has been a promising field to invest in for local communities, government, NGOs, tourism companies and researchers. Over the last decade, UNESCO has been actively developing the Global Geoparks Network, objects of geological tourism.

Databases and web technologies, such as web GIS, web maps integrated into portals, have an increasing influence on tourism and popularization of scientific knowledge to the

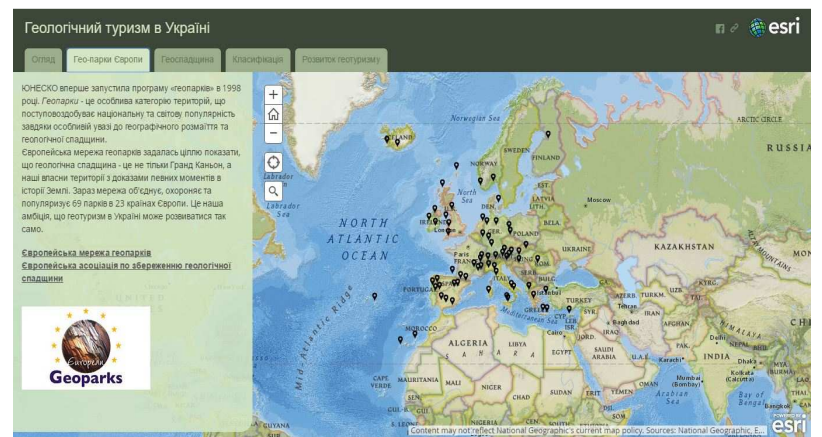

Fig.5. European geoparks

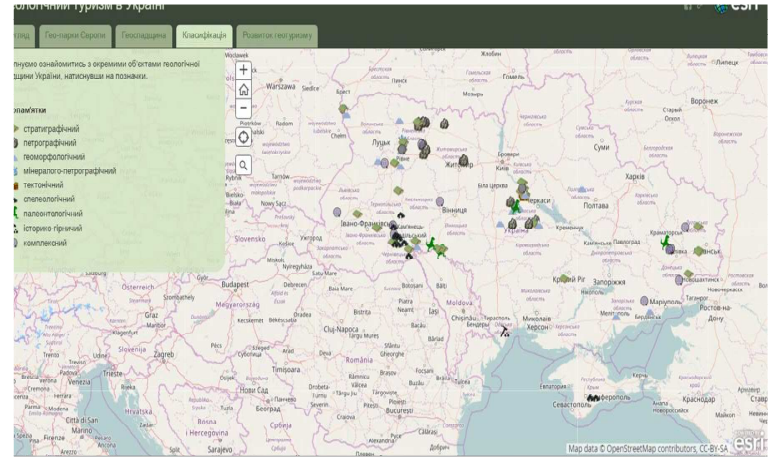

Fig.7. Classified geological landmarks

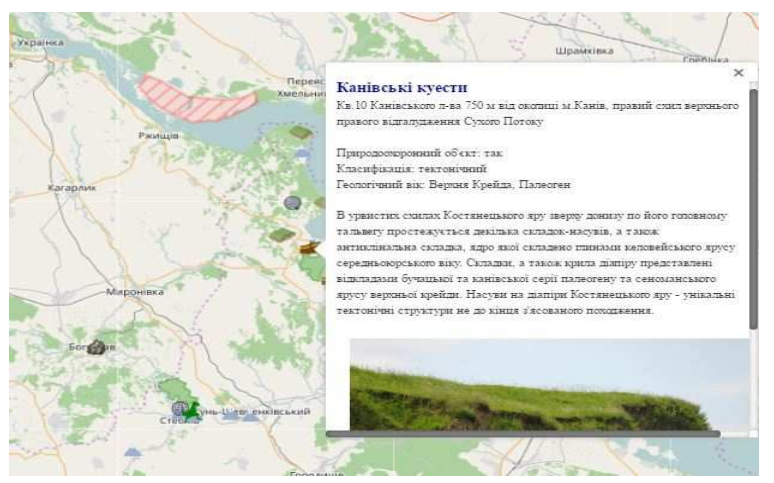

Fig.9. Information popup window of a local geological landmark "Kanivski kuesty"

general public. Unfortunately, even simple interactive web maps that exist on tourism websites in Ukraine often are unattractive and not user-friendly, rely on outdated technology.

This paper shows that it is possible to create a web resource to popularize and collect information on geological natural landmarks with little or no financial cost. It provides potential visitors with information in a visually appealing way. Geotourism as a novel field of Ukrainian tourism, science communication and environmental protection should actively 
rely on GIS and web technologies to make geosites attractive not only to scientists and nature lovers, but average tourists. On the other hand, databases and GIS can serve as means of collecting, storing, monitoring and managing geological landmarks. So, the concept of a geoportal "Geological tourism of Ukraine" was developed to synthesize and visualization information on geological heritage.

The prototype relies on PostgreSQL software and ArcGIS Online platform. The database allows querying for different classes, geological age, tectonic structures of the geosites, working with spatial data through PostGIS extension, and creating cartographic representation of the data. Actualization of the database with new data on geolandmarks is anticipated. Then, web mapping was used to visualize spatial information and provide user interaction. Future work will include updating the database and creating a fully-functioning geoportal with server technologies, querying possibility and a larger informative component.

The geoportal can facilitate publication of other related products (e.g. printed guides, oral geotours, interactive applications). It integrates scientific and educational components of geotourism, and more precisely, it generates understanding and appreciation of geological components of the environment.

The idea of creating a separate portal is attractive because it will enable the average user to get an interesting interactive information in one place, thus sklonyayuchy its direct participation in the geological tourism.

\section{REFERENCES}

1. Bubnyak I.S., Solyetski A., 2013. Navchalni materialy Heo-Karpaty. Krosno Ruthenus, 3-11. (https://issuu.com/jacek wnuk/docs/24.09.2013 materialy szkoleniowe ua) (in Ukrainian).

2. Bezvynnyy V.P., Biletskyy S.V., Bobrov O.B. ta in., 2006. Heolohichni pamyatky Ukrayiny. U 3T. Za red. V.I. Kalinina, D.S. Hurskoho, I.V. Antakovoyi. Kyiv, DIA, Vol.1, 320 (in Ukrainian).

3. Hose T.A., 1995. Selling the story of Britain's Stone. Environmental Interpretation, Vol.10-2, 16-17.
4. Newsome D., Dowling R., Leung Y.F., 2012. The nature and management of geotourism: a case study of two established iconic geotourism destinations. Tourism Management Perspectives, Vol.2-3, 19-27.

5. Heolohichnyy turyzm v Ukrayini (http://arcg.is/2fGzZU2) (in Ukrainian).

6. Hrytsenko V.P., Ishchenko A.A., Rusko Yu.A., Shevchenko V.I., Hrytsenko V.P., 1995. Heolohichni pamyatky pryrody Ukrayiny: problemy vyvchennya, zberezhennya ta ratsionalnoho vykorystannya. Kyiv, 10-11 (in Ukrainian).

7. Domashevska M.S., 2013. Zastosuvannya HIS ta danykh DZZ dlya heolohichnoho turyzmu (na prykladi pivdennoyi chastyny Krymu). Suchasni problemy heolohiyi. Zbirnyk naukovykh prats do 155-richchya $\mathrm{z}$ dnya narodzhennya akademika Pavla Apollonovycha Tutkovskoho, Kyiv, Fiton, 345-348 (in Ukrainian).

8. Eder F., Patzak M., 2004. Geoparks - geological attractions: a tool for public education, recreation and sustainable development. Episodes, 27(3), 162-164.

9. Chomko D.F., Ostroukh O.A., 2009. Suchasnyy stan ta problemy vykorystannya HIStekhnolohiy $\mathrm{v}$ heolohichnykh doslidzhennyakh. Visnyk Kharkivskoho natsionalnoho universytetu imeni V.N. Karazina, Vol.82, 99102 (in Ukrainian).

10.Norzaini A., Sharina A.H., Ong P.L., Salsela S., Ibrahim K., 2010. Public Education in Heritage Conservation for Geopark Community. Procedia-Social and Behavioral Sciences. Vol.7, 504-511.

11.Newsome D., Dowling R., Leung Y.F., 2012. The nature and management of geotourism: a case study of two established iconic geotourism destinations. Tourism Management Perspective, Vol.2-3, 19-27.

12.Behal T.O., 2013. Upravlinnya zemelnymy resursamy $\mathrm{v}$ systemi pryrodookhoronnykh zakhodiv na terytoriyakh rozmishchennya heolohichnykh pamyatok pryrody. Suchasni problemy heolohiyi, Zbirnyk naukovykh prats do 155-richchya z dnya narodzhennya akademika Pavla Apollonovycha Tutkovskoho, Kyiv, Fiton, 333-335 (in Ukrainian).

13.Pavlovskyy V.A., Korbut H.O., Pamirskyy M.S., Pavlovskyy V.A., 2010. Heolohichnyy turyzm yak perspektyvnyy resurs Zhytomyrskoyi oblasti. Materialy III Vseukrayinskoyi naukovo-krayeznavchoyi konferentsiyi, 165169 (in Ukrainian). 
14.Pylypchuk O., Zuryan T., Lykhosherstov A., Lokhva Ya., 2013. Stvorennya suchasnoyi heoinformatsiynoyi systemy yevropeyskoho typu v heolohichniy haluzi Ukrayiny. Suchasni problemy heolohiyi: zbirnyk naukovykh prats do 155-richchya $\mathrm{z}$ dnya narodzhennya akademika Pavla Apollonovycha Tutkovskoho. Kyiv, Fiton, 345-348 (in Ukrainian).

15.Zatserkovnyy V.I., Serhiyenko V.V., Simakin Yu.S., 2010. Vykorystannya heoinformatsiynykh tekhnolohiy dlya stvorennya web atlasu Chernihivskoyi oblasti. Vcheni zapysky Tavriyskoho natsionalnoho universytetu imeni V.I.Vernadskoho. Seriya Heohrafiya. Vol.24 (63), Iss.2, Part 2, 64-68. (in Ukrainian).

16.Zatserkovnyy V.I., Tishayev I.V., Virshylo I.V., Demydov V.K., 2016. Heoinformatsiyni systemy v naukakh pro Zemlyu. Nizhyn, NDU imeni M.Hoholya, 510. (in Ukrainian).

17.Volodymyr Gryshyn, Lev Gembarskyi, Volodymyr Snisarenko, 2015. Existing and projected artificial islands and their purpose. Underwater Technologies, Vol.02, 32-39.

18.Nellya Leshchenko, 2016. Pre-project research cycle of the architectural environment of the small town's historical center as an analytical stage of it reconstruction. Underwater Technologies, Vol.03, 66-74.

19.Eugenia Kazakova, 2017. Problems and directions of reconstruction of historical centers of small settlements of the Volyn region (on the example of Klevan, Rivne region). Underwater Technologies, Vol.05, 84-91.

20.Nikolay Zhuk, Myron Nazarian, Yury Stelmakhov, 2015. Great silk road: modern problems of reconstruction. Underwater Technologies, Vol.01, 59-64.

\section{Геопорталы как средство популяризации геологического наследия Украины}

\section{Виталий Заиерковный, Наталья Оберемок, Полина Березина}

Аннотация. Показана проблема использования геологических памятников природы (ГПП) региона в научных и образовательных целях, которая является частью общей проблемы сохранения и использования геологического наследия Земли, приобрела международное значение. Отечественный и международный опыт свидетельствует о необходимости создания тематических ГЕОТУР, опорными объек- тами которых служат геологические памятники природы (ГПП).

Представлена концепция геологического туризма, памятников природы и их значимости. Раскрыты такие важные смежные понятия, как геонаследие, геоконсервация и геопарк. Кратко описана идея классификации геологических памятников. Изложены концепция и методология создания геопортала, посвященного геологическому туризму в Украине, с последующими итогами результатов. Разработанные вебГИС должны способствовать распространению знаний среди общей массы и систематизации информации об объектах геологического наследия.

Геологический туризм в Украине имеет потенциал улучшить социально-экономическое положение местных общин, сохранить геологические объекты и популяризировать науки о Земле. На сегодня не существует реального инструмента для привлечения внимания общественности к геонаследию и геотуризму, что подтверждает большую актуальность данной научной работы.

Создание геопортала позволит гражданам интерактивно взаимодействовать с картой геологических памятников в Украине, получать интересную информацию по объектам, тем самым приобщаясь к геологическому туризму. Для достижения поставленной цели решаются следующие задачи: сбор информации о геологических памятниках, создание дизайна базы данных и ее наполнение, создание интерактивных карт, разработка концепции геопортала и его прототипа.

Основное внимание сосредоточено на рассмотрении концепции геотуризма, международного опыта его применения и важности использования веб-ГИС инструментов для его популяризации. Проанализировав наработки украинских ученых в этой сфере, результаты международных конференций и проектов, следующим этапом стала разработка собственной концепции геопортала с использованием вебтехнологий и геоинформационных систем.

Ключевые слова: геотуризм, геологический туризм, геологические памятники природы, геопортал, веб-ГИС, ГПП, пространственная база данных. 